\title{
LANDSLIDES SUSCEPTIBILITY ZONATION OF THE TERRITORY OF NORTH MACEDONIA USING ANALYTICAL HIERARCHY PROCESS APPROACH
}

\author{
Ivica Milevski ${ }^{*}$, Slavoljub Dragićević ${ }^{2}$ \\ ${ }^{1}$ Faculty of Natural Sciences and Mathematics, Ss. Cyril and Methodius University, \\ Skopje, Republic of Macedonia \\ ${ }^{2}$ Faculty of Geography, University of Belgrade, Belgrade, Serbia \\ e-mail: ivica@pmf.ukim.mk
}

\begin{abstract}
Landslides are natural disasters that have an impact in many areas around the world including the territory of the Republic of Macedonia. In this country, about 300 large landslides are registered, most of which cause serious damage to the infrastructure almost every year. In that sense, the mapping of sites that are susceptible to landslides is essential for the management of these areas. This is a crucial step to prevent landslides in places where this could be expected or to minimize its damages. Therefore, a heuristic approach of Analytical Hierarchy Process (AHP) combined with Geographic Information System (GIS) and Remote Sensing (RS) is used in this work for the assessment of potential landslide areas in the Republic of Macedonia. In the procedure, 6 triggering factors indicating a strong influence on the landslide activity are selected, including lithology, slope angle, land cover, terrain curvature, distance from rivers and distance from roads. Through the procedure, expert-based weight of these factors is made. The LS model is produced with the summing up of the factor layers in the form of harmonized raster grids. Finally, the values of the grid model are classified according to the quantiles and natural breaks scheme. The produced maps show acceptable results confirmed by validation methods and ROC analysis, indicating that about $40 \%$ of the country area is under high and very high landslide susceptibility. This approach can be further improved if combined with statistical methods in the form of a hybrid model.
\end{abstract}

Keywords: Landslide susceptibility; landslide hazard zonation; AHP; ROC; AUC

\section{INTRODUCTION}

With large areas of erodible crystalline rocks (gneiss, mica-schists, other schists), sandstones, lacustrine and fluvial deposits, steep slopes (39.5\% of the area above $15^{\circ}$ ), semi-arid climate and sparse vegetation, landslides are very common in North Macedonia. Frequent storms with heavy or prolonged rains contribute to excess runoff and hillslope instability. Landslides, slumps, and soil creep are especially often on the valley sides, where Neogene lacustrine sands and sandstones are superimposed over inclined impermeable clay and schist layers. In more compact weathered rocks (igneous, limestone, marble), rockfalls, rockslides, debris flows, and other gravitational processes occur. In addition to the natural factors, increased human impact (road-cuts and heavy constructions on steep terrain) significantly contribute to the activation of landslides resulting in economic damages and even casualties $[1,2]$.

To reduce the risk from the landslides, identification and mapping of the landslide-prone area is a very important task. This information is often described in the form of landslide susceptibility zonation (LSZ) [3-9]. According to Brabb [10], landslide susceptibility (LS) is the likelihood of a landslide to occur in an area on the basis of local terrain conditions. It is the degree to which a terrain can be affected by slope movements, i.e., an estimate of "where" landslides are likely to occur. According to van Westen et al. [11], a landslide susceptibility analysis (LSA) involves essentially four main phases: (a) the production of a landslide inventory map, (b) the assessment of event - controlling factors that influence the landslide manifestation, (c) the appli- 
cation of appropriate methods for determining the weights of each factor and (d) the compilation of the landslide susceptibility map using a GIS procedure. In most cases, the complexity of the causative and triggering factors, their unknown interrelationship and the lack of knowledge, make the LSA a very demanding task [12]. However, with the help of GIS, it is possible to integrate spatial data of different layers to determine the influence of the causative factors on landslide occurrence [13-17].

Besides the high frequency and yearly damages of up to several million euro, in the Republic of Macedonia, only a few small-scale studies of GIS and RS based landslide area assessments were made with different success. Thus, Milevski et al. [18] use SAGA GIS-based cluster classification of landsliderelated factors for susceptibility zonation of Gevgelija-Valandovo basin, and later, frequencyratio model was implemented in landslide hazard zonation of Pehčevo Municipality [19, 20], Vlaina Mountain [21] and index-based method in landslide susceptibility of the Kriva River catchment [22]. Meanwhile, Peševski [23] made a very detailed landslide inventory of the Polog-Reka (NW) area as a basis for landslide hazard zonation (LHZ).

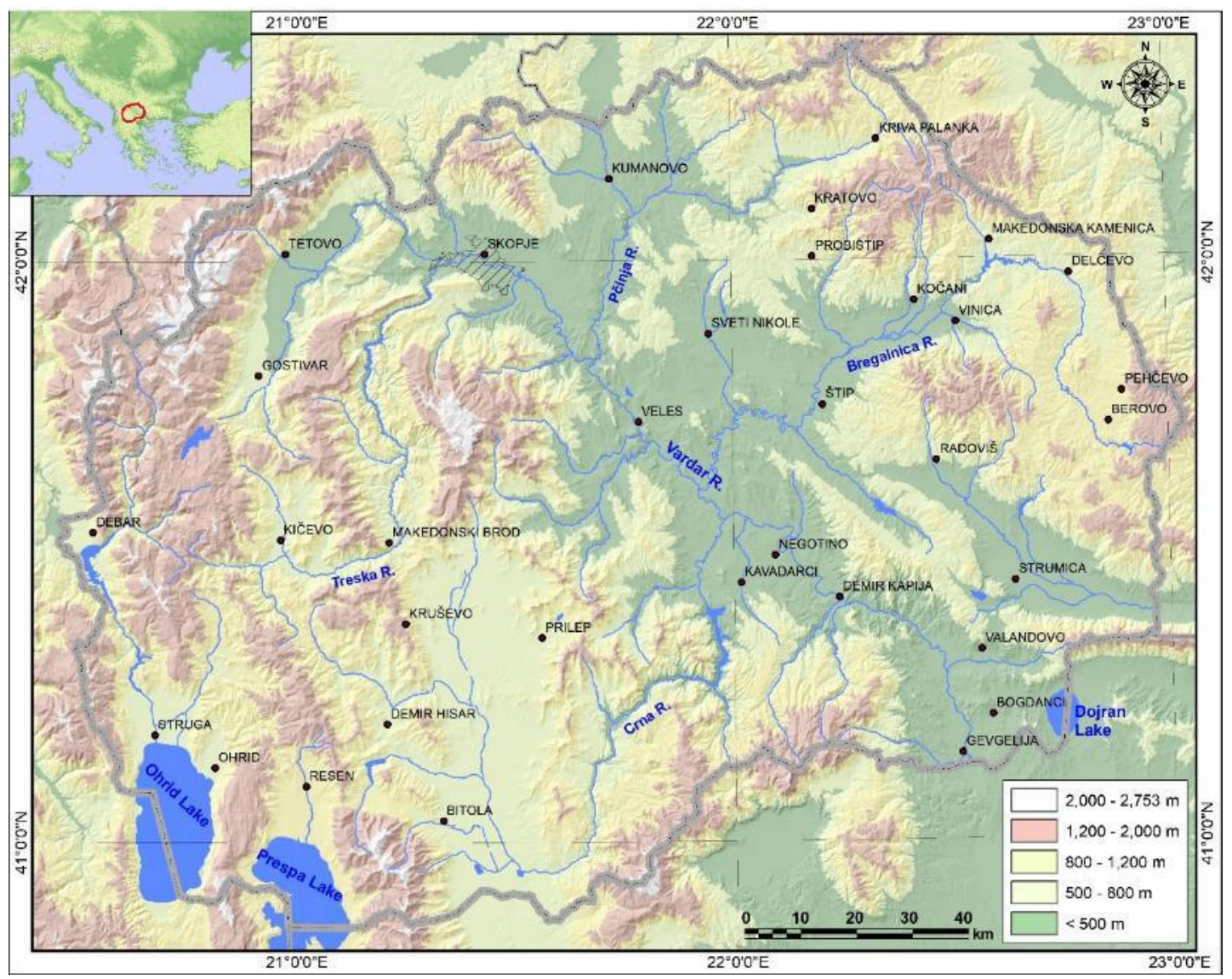

Figure 1. Geographic location of North Macedonia

Currently, Macedonia is without detailed (national-scale) landslides inventory and landslide susceptibility zonation whichis necessary for any land use planning purpose. Thus, the aim of this paper is to make an attempt to determine areas or zones in the country susceptible to landslides. That is made with an analytical hierarchy process (AHP) implemented through geographical information system (GIS) and remote sensing (RS). The advantage is the cost-saving and large-area identification of hazard zones. Therefore, it can be used in hazard zoning of the disaster management authorities [24].

\section{METHODOLOGY}

Modeling and mapping of landslide-prone areas on a regional scale is a very complex task, because of many natural and anthropogenic factors related to landslide processes. The first step in this regard is the selection of the most suitable method for landslide susceptibility assessment. Keeping in mind the large extent of the area and the small landslide inventory, heuristic approach with the Analytical Hierarchy Process (AHP) is selected as a method in this paper. 
The AHP is one of the most popular MultiCriteria Decision-Making (MCDM) tools for formulating and analyzing decisions $[25,26]$ and it consists of three main operations, including hierarchy construction, priority analysis, and consistency verification [27]. Recently, this approach is widely used in the GIS-based assessment of landslide susceptibility $[28,29]$. Within the approach, comparison of the contributions of different landslide triggering factors is estimated, where the weight of each criterion is determined by expert-based pair-wise comparison matrix as described by Saaty and Vargas [30].

The implementation of AHP methodology in the assessment of landslide susceptibility firstly requires the finding of interdependencies between the most important influential attributes. It is highly recommended to normalize the values of input attributes and classify them into a specific number of classes. In our case, a 5-class range was used, meaning that 1 is the least likely, while 5 is highly likely to trigger landslide occurrence. Reclassified and ranged attributes, with their weights, give the final impact on the susceptibility model. Thus, a proper selection of most influencing factors or triggers is a very important step in this process.

There is a lort of researches worldwide about the selection of most important landslide triggering factors. According to Crozier [4], depending on the characteristics of the study area, at least three triggering factors have to be included in GIS analysis including topography, lithology and land use. Donati and Turrini [31] indicate that the most common landslide triggering factors are: lithological units, tectonic features, slope angle, proximity to (road and drainage) networks, land cover and rainfall distribution. In the preliminary LS mapping on the national level in Slovenia, Komac and Zorn [32] used 6 factors as a most relevant: lithology, surface inclination, surface curvature, land use, maximum 24-hour precipitation, and surface aspect. Thus, the proper selection is of greater importance than the number itself. Based on the previous knowledge and experience, and keeping in mind data availability, in this work 6 landslide triggering factors were considered: slope, lithology, land use, plan curvature (convexity), distance from streams and distance from roads. When the aspect is analyzed, a weak correlation with landslide distribution is shown, and because of that, aspects as a factor are excluded in the modeling. Actually, numerous other studies are controversial about aspects-landslides correlation [3336]. The similar is with precipitations which do not have significant spatial differences (in average 500 to $800 \mathrm{~mm}$ per year) and there is no accurate data about the heavy rain distribution. In the entire procedure, SAGA GIS v.7 software is used, where all of the factors were converted to raster grids with 20$\mathrm{m}$ resolution. For the purpose of the study, each factor is divided into proprietary classes according to its range, distribution and structure. The data for slope and curvature were calculated from the $20 \mathrm{~m}$ digital elevation model (DEM) of the entire country, based on the combined freely available 20-m ALOS and 30-m SRTM DEM. Slope values are classified into 5 classes $\left(0-5^{\circ}, 5-10^{\circ}, 10-30^{\circ}, 30-45^{\circ}\right.$, and more than $45^{\circ}$ ). In a similar way, according to the values, terrain (profile) curvature is split into 5 classes: highly convex, convex, flat, concave and highly concave. The lithology grid was prepared from a 1:100,000 scale digitalized geological map of the country with 78 lithological units: from Precambrian gneiss and mica-schist through Mesozoic limestone to Cenozoic sediments of marine, lacustrine and riverine origin. These lithological units are reclassified according to the erodibility and engineeringgeological features into 5 classes: from clastic sediments and tuffs to very resistant rocks (marble, limestone, quartzite etc.). Land use layer was prepared according to CORINE (CLC2012) general classification hierarchy. Distances from the streams were derived using DEM-based drainage network tool, while the distance from the roads was prepared from the latest (2018) freely available OSM (Open Street Map) road network in vector format. According to the relevant research experience and consulted bibliography, 5 buffer zones for roads (on $50 \mathrm{~m}$ steps) and streams (on $100 \mathrm{~m}$ steps) were created and rasterized.

In our study, previously selected factors are weighted according to the AHP matrix by the combination of the experts opinion, the field experience of the authors, as well as the results of landslide susceptibility assessment (LSA) from the former researches on smaller (test) areas in the country [1823]. For the ranking of factor classes, two approaches are used: expert opinion in combination with statistical analysis of the landslide frequency for that class.

One of the basic requirements for AHP-based landslide susceptibility modeling is to have sufficient landslide inventory as a basis for the validation of the model accuracy. However, in Macedonia, detailed inventory is not prepared on the national level yet. For that reason, considering the available time, we prepare inventory based on the landslide records from the field trips and our previous works, then different kinds of maps (especially geological one), landslide records with remote-sensing of satellite imagery, reports from the media etc. The final land- 
slide dataset consists of 270 landslides as the validation dataset used during the verification of the results produced from the model.

\section{RESULTS}

To acquire factor weights in AHP, each factor is rated against every other factor by assigning a relative dominant value between 1 and 9 to the intersecting cell. When the factor on the vertical axis is more important than the factor on the horizontal axis, this value varies between 1 (equally important) and 9 (very important). Conversely, the value varies between the reciprocals $1 / 2(0.5)$ and $1 / 9(0.11)$. Since we have used 6 parameters, the comparison matrix has 36 boxes (Table 1). The matrix-based weight of the factors, as well as the consistency ratio
(CR) of the matrix, is calculated with the AHP Excel template [37]. According to the prepared landslide inventory, own experience and relevant publications, most of the landslides in the Republic of Macedonia occur on moderate slopes $\left(10-30^{\circ}\right)$ and on terrain composed by clastic sediments (Neogene lacustrine deposits, colluvium sediments) and schists (mica-schists, green-schists etc.). Also, a significant number of landslides occur in terrains with weak vegetation (pastures, grasslands, bare and erodible rocks), but also in the cultivated land on steep terrains and in urban areas. The statistically substantial number of landslides are located on the distance up to 100-200 $\mathrm{m}$ from the streams and up to $50 \mathrm{~m}$ from the roads, mostly as a large roadside rock falls. Based on these facts, the AHP matrix in Table 1 and the class ranks in Table 2 are prepared.

Table 1. AHP comparison matrix for the selected factors

\begin{tabular}{lccccccc}
\hline Factor & Slope & Lithology & Land cov. & Conv. & Roads & Streams & Weight \\
\hline Slope & 1 & 3 & 3 & 4 & 3 & 4 & 0.378 \\
Lithology & 0.33 & 1 & 1 & 3 & 3 & 4 & 0.212 \\
Vegetation & 0.33 & 1 & 1 & 1 & 2 & 3 & 0.154 \\
Convergence & 0.25 & 0.33 & 1 & 1 & 1 & 2 & 0.104 \\
Roads & 0.33 & 0.33 & 0.5 & 1 & 1 & 1 & 0.086 \\
Streams & 0.25 & 0.25 & 0.33 & 0.5 & 1 & 1 & 0.066 \\
\hline
\end{tabular}

Consistency ratio (CR) which shows how consistent is the hierarchy of the factors in the AHP matrix is a very important parameter. Saaty [25] suggest that the CR must be less than 0.1 to accept the computed weights otherworld the ratings should be re-evaluated. $\mathrm{CR}$ for the matrix in Table 1 is 0.035 indicating the acceptable consistency of the comparison matrix.

The factor class ranking $(\mathrm{R})$ is made in a range of 1 (insignificant influence) to 5 (highest influence for that factor). Thus, it is found that the highest number of recorded landslides (86) is present in the slope class of $10-30^{\circ}$ and that class is ranked with the value 5 . Contrary, in the slope class of $0-5^{\circ}$ only 3 landslides are registered so that the slope class is ranked with 1. A similar procedure is taken for all other factors. However, some expertbased evaluation is made when the statistical results are problematic. That is the case with road buffers wherein the first buffer $(0-50 \mathrm{~m})$ statistically very large number of landslides is found (135). Our explanation is that most of the recorded landslides with field surveys (for this study) were visible from the roads. For that reason, a weighting of the factor proximity to roads was lower on the matrix scale (but the $<50 \mathrm{~m}$ road buffer is with a value of 5).

Finally, the weight of each factor is multiplied by its rankings $\mathrm{R}$ (based on the qualitative and expert rankings [38]), then multiplied by 5 and rounded to the final value (Table 2 ).

The final map (Figure 2) is calculated by summing up the values of each grid cell of all of the 6 digital layers. The values of the resulting model are in the range from 2.6 (areas with the lowest potential for landslides) to 26 (areas with the greatest potential for landslides or already under landslides).

However, the LS map with continuous values provides an only general view of the landslide-prone areas. For better differentiation and landslide susceptibility zoning, the classification of these values must be done. In that sense, using GIS-based natural breaks and quantile classification, we try to classify LS values into five classes of very low, low, medium, high and very high landslides susceptibility zones. Both classifications are performed in SAGA GIS software and their results are compared to ROC curve validation. 
Table 2. The weight values of factors used for AHP model

\begin{tabular}{|c|c|c|c|c|c|c|c|}
\hline Factor & Rank & $\mathbf{R}^{*} \mathbf{W}^{* 5}$ & Value & Factor & Rank & $\mathbf{R} * \mathbf{W} * \mathbf{5}$ & Value \\
\hline$w=0.378$ & & & & Cultivated lands & 3 & 3.1 & 3 \\
\hline $0-5^{\circ}$ & 1 & 1.9 & 2 & Urban areas & 3 & 3.1 & 3 \\
\hline $5-10^{\circ}$ & 3 & 5.7 & 6 & Transitional forests & 2 & 1.5 & 2 \\
\hline $10-30^{\circ}$ & 5 & 9.5 & 10 & Dense forests & 1 & 0.8 & 1 \\
\hline $30-45^{\circ}$ & 4 & 7.6 & 8 & Water bodies & 0 & 0.0 & 0 \\
\hline$>45^{\circ}$ & 2 & 3.8 & 4 & Convexity $\quad w=0.104$ & & & \\
\hline Lithology & & & & Concave & 5 & 2.6 & 3 \\
\hline Clastic sediments & 5 & 5.3 & 5 & Highly concave & 4 & 2.1 & 2 \\
\hline Schists & 4 & 4.2 & 4 & Flat & 3 & 1.6 & 1.5 \\
\hline Gneiss & 3 & 3.2 & 3 & Convex & 2 & 1.0 & 1 \\
\hline Flysch & 3 & 3.2 & 3 & Highly convex & 1 & 0.5 & 0.5 \\
\hline Granitic rocks, andesite & 2 & 2.1 & 2 & Roads $\quad w=0.086$ & & & \\
\hline Quartzite, amphibolite & 1 & 1.1 & 1 & $0-50 \mathrm{~m}$ & 5 & 2.1 & 2 \\
\hline Limestone, marble & 1 & 1.1 & 1 & $>50 \mathrm{~m}$ & 1 & 0.4 & 0 \\
\hline Land Cover $\mathrm{w}=\mathbf{0 . 1 5 4}$ & & & & $\mathrm{w}=\mathbf{0 . 0 6 6}$ & & & \\
\hline Bare rocks & 4 & 3.9 & 4 & $0-100 \mathrm{~m}$ & 5 & 1.6 & 2 \\
\hline Pastures & 4 & 3.1 & 4 & $>100 \mathrm{~m}$ & 1 & 0.3 & 0 \\
\hline
\end{tabular}

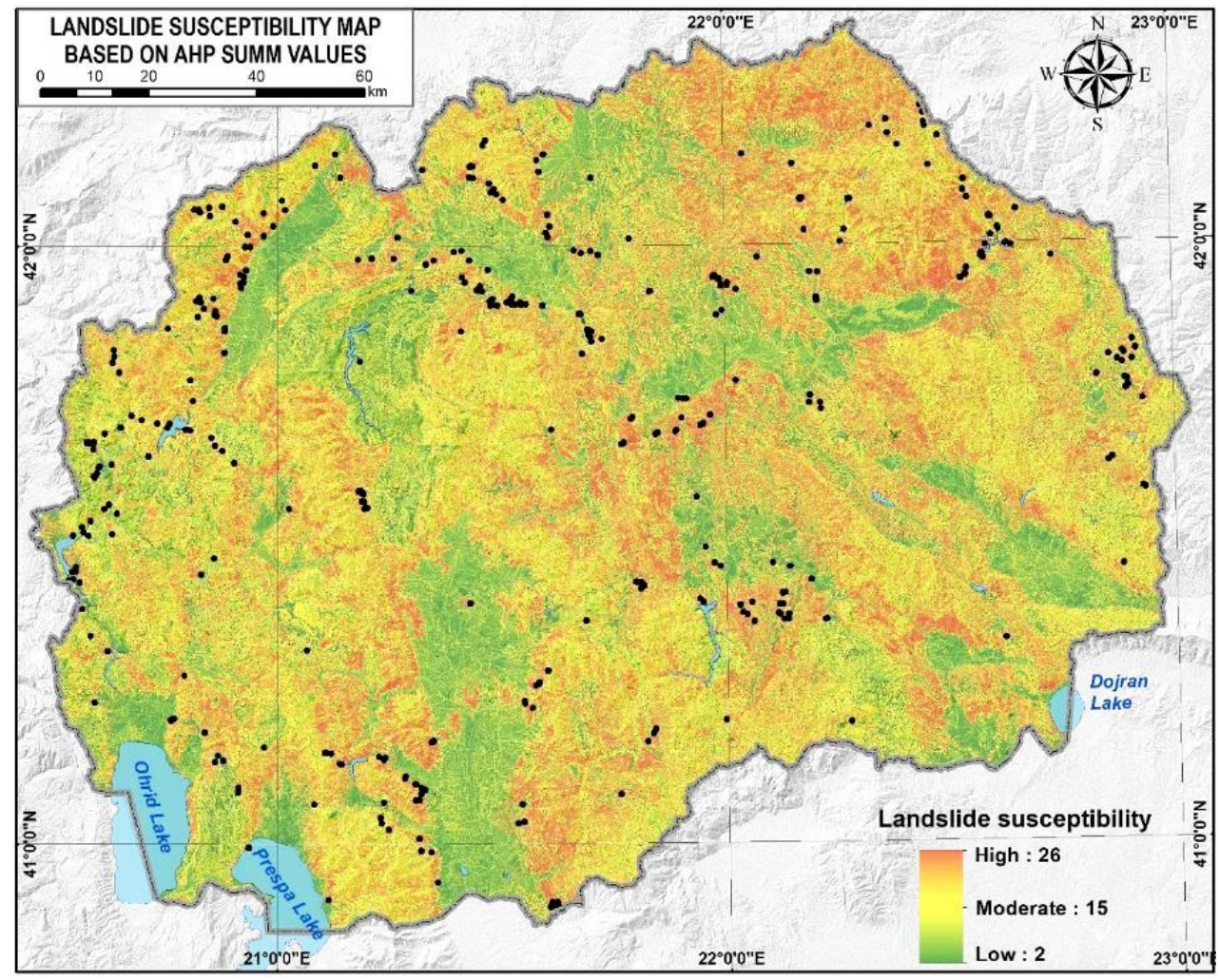

Figure 2. Unclassified AHP-based landslide susceptibility map of North Macedonia

Natural breaks (or Jenks) algorithm performing classification by grouping similar values while maximizing the differences between classes. It gives good results when the histogram shows evident breaks, and for this reason [39]. During this classification method, a problem appears with too small areas of very low and very high susceptibility zones. For that reason, natural breaks (jenks) method is updated with the histogram specific breaks (with the following ranges: $2-12,12-14,14-16,16-18$ and 1826 for the very high LS zone) and the result is shown in Figure 3. 


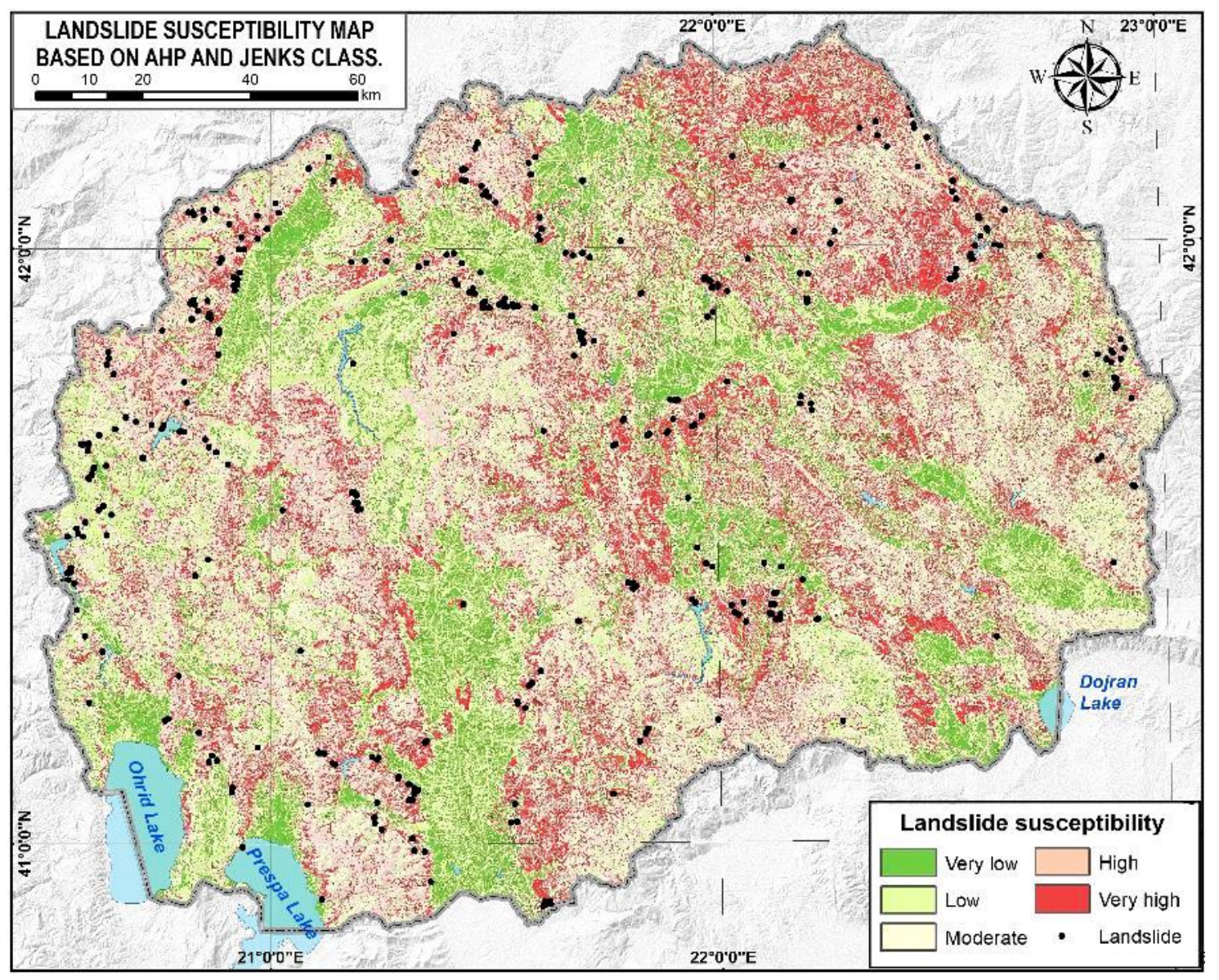

Figure 3. AHP-based landslide susceptibility map of North Macedonia according to the natural breaks (jenks) classification

The second method, i.e. quartile classification is well suited to linearly distributed data assigning the same number of data values to each class. There are no empty classes or classes with too few or too many values [40]. The map prepared with quantile classification (Figure 4) is with a slightly more dominant high and very high landslide susceptibility zone. That is even more evident from the map crops which cover the Skopje basin (Figure 6). Evidently, there is a more significant difference in very high landslide susceptibility area which is confirmed with validation tables. However, the generally small difference is only a result of the class breaks threshold and not related to the AHP procedure itself.

In order to choose the more accurate map of both implemented classifications, the validation technique was used to compare known landslide location data with the landslide susceptibility zonation map. That is made with validation data and ROC curve derived AUC (Area Under Curve).

Both GIS-based classifications (quantiles and natural breaks) shows the acceptable accuracy of the implemented model because more than $70 \%$ of the landslides in the inventory are in the class of high
(H) and very high $(\mathrm{VH})$ landslide susceptibility (Table 3). However, natural breaks classification here is superior because only 18 landslides fall in the class of low and very low susceptibility vs 31 landslides in quantile classification. Also, within natural breaks classification, 203 landslides (75\%) fall in the zone of high and very high susceptibility vs only 193 landslides $(71.6 \%)$ in quantile classification. However, the number of landslides (in \%) compared with the area (in \%) of high and very high susceptibility class, show an equal ratio for both classifications i.e. 3.61. From the other side, the same ratio for the areas with low and very low susceptibility class is 0.39 for natural breaks and 0.57 for quantiles which favors natural breaks. Taken that the ratio tends to be as close to 0 for very low LS class, and increase well above 1 for very high LS class, then natural breaks classification shows slightly better overall accuracy. Thus, according to the AHP map prepared with natural breaks classification, $93.4 \%$ of the landslides fall within very high, high and moderate landslide susceptibility zones (covering $66.6 \%$ of the country area). 


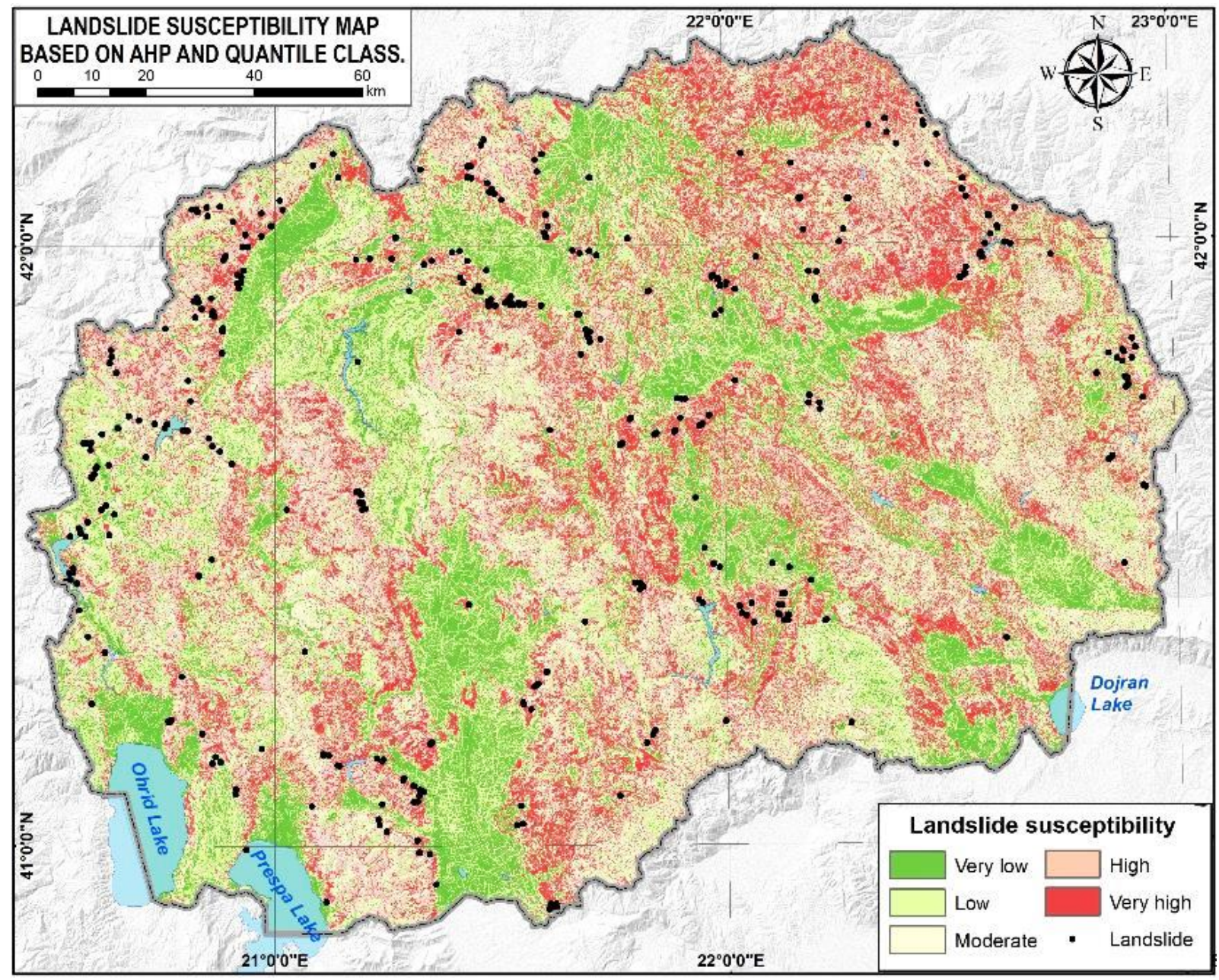

Figure 4. AHP-based landslide susceptibility map of North Macedonia according to the quantile classification

Table 3. Data for AHP-based LSZ according to natural breaks and quantile classification

\begin{tabular}{l|rrrrr|rrrrr}
\hline & \multicolumn{4}{|c|}{ Natural breaks (jenks) classification } & \multicolumn{5}{c}{ Quantile classification } \\
\hline LS class & Area km & Area \% & Lds.N & Lds.\% & Ratio & Area km ${ }^{2}$ & Area \% & Lds.N & Lds.\% & Ratio \\
\hline very low & 3882.1 & 15.1 & 7 & 2.6 & 0.17 & 5142.6 & 20.0 & 11 & 4.0 & 0.20 \\
low & 4697.7 & 18.3 & 11 & 3.9 & 0.22 & 5091.2 & 19.8 & 20 & 7.2 & 0.37 \\
moderate & 6190.1 & 24.1 & 50 & 18.4 & 0.77 & 5271.2 & 20.5 & 46 & 17.1 & 0.83 \\
high & 6227.9 & 24.2 & 98 & 36.2 & 1.49 & 4962.6 & 19.3 & 101 & 37.5 & 1.94 \\
very high & 4715.2 & 18.3 & 105 & 38.8 & 2.12 & 5245.5 & 20.4 & 92 & 34.1 & 1.67 \\
\hline Total & 25713.0 & 100.0 & 270 & 100 & & 25713.0 & 100.0 & 270 & 100.0 \\
\hline
\end{tabular}


An alternative way to the above statistics is the receiver operating characteristic (ROC) value and the area under the ROC curve (AUC). This method has been widely used as a measure of performance of a predictive rule. ROC plots the different accuracy values obtained against the whole range of possible threshold values of the functions, and the AUC serves as a global accuracy statistic for the model, regardless of a specific discriminate threshold. This curve is obtained by plotting all combinations of sensitivities and proportions of false negatives (1-specificity) which may be obtained by varying the decision threshold. The range of values of the ROC curve area is $0.5-1$ for a goodfit, while values below 0.5 represent a random fit [41]. In our case, for better assessment of the model, except the recorded "true-positive" landslides (value
1) in the validation dataset, 540 "false-positive" landslides (value 0) are also selected as random points sampling from DEM (using SAGA GIS). According to our results, with non-random spatial sampling (i.e. on flat areas, highly convex areas etc.), AUC is inadequately high compared with random sampling (excluding the areas of already confirmed-recorded landslides).

The ROC curve and AUC in this study are calculated in SPSS-statistical software (trial version) and presented in Figure 5. It is interesting that both AHP-based maps have almost the same AUC with the very slight advantage of the natural breaks classification $(0.780$ vs 0.776$)$. Thus, for both, there is nearly $78 \%$ agreement with the landslide locations which is a reasonable result at this scale.

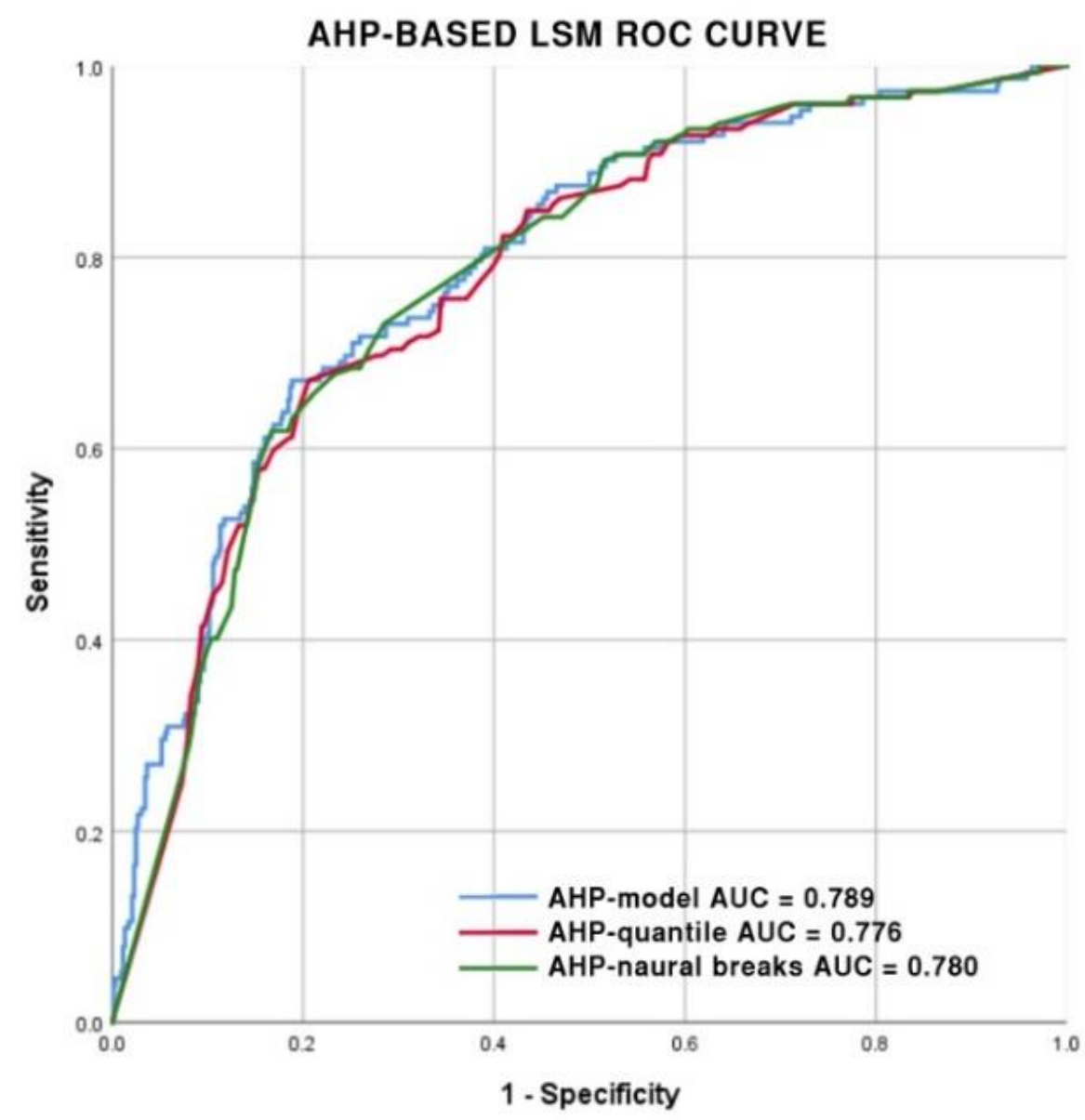

Figure 5. ROC curve and AUC for the AHP-based LS maps produced in this study 


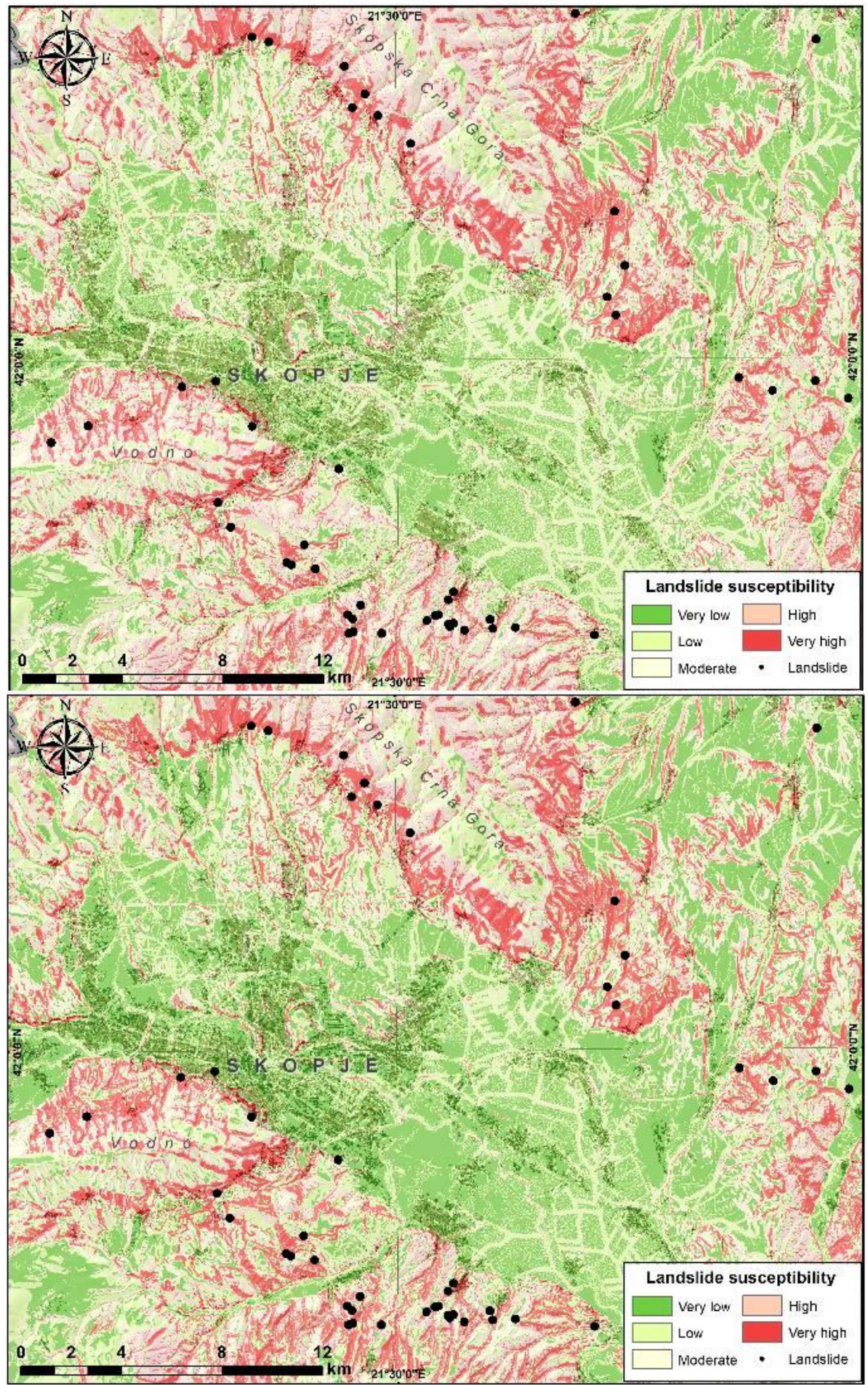

Figure 6. Part of the AHP landslide susceptibility map in the area of Skopje Basin according to the natural -break (up) and quantile (bottom) classification

\section{CONCLUSIONS}

LSA is a crucial step to prevent landslides in places where this could be expected or to minimize its damages. At the regional scale, statistical methods like frequency ratio are generally considered the most appropriate for LS mapping because they are objective, reproducible and easily updatable [33]. However, for the implementation of these methods, sufficient landslide inventory is needed. Without that, a semi-quantitative approach can be used as in this paper where Analytical Hierarchy Process (AHP) in a GIS environment is applied. Within the procedure, six factors are selected, analyzed and 
weighted according to the expert judgment and statistical rankings from the few case studies through the country. Among the factors, slope, lithology, plan curvature, land use, distance from streams and distance from roads are used as the most influencing. The final model is prepared as a sum of weighted grid cells values for each of the 6 factors layers. With further quantile and natural breaks classification, 5 landslide susceptibility classes are defined and represented on the map. Even with very limited landslide inventory, statistically, there is about $78 \%$ agreement (AUC value) between the maps (models) and 270 landslide locations, which is an acceptable result taking into consideration the scale of analysis. It is interesting that both classifications show very similar AUC in slightly favor of natural breaks (0.78) and indicate that about $40 \%$ of the country area is under high and very high landslide susceptibility. Regionally, most of the area with high and very high landslide susceptibility in Macedonia is extended over hilly terrains and in mountain foots, on the side of valley bottoms in gorges, and on the sides of depressions and basins which are usually covered with Neogene lacustrine sediments (Fig. 2, 3 and 4). Thus, according to the maps, the areas in the central part of the country (Tikveš depression), the north-east part on the hillslopes of Osogovo and Bilino mountains and upper Bregalnica catchment, on the edges of Skopje Basin (Fig. 6), and the foothills of Sara Mountain are among the most susceptible to landslides. On the contrary, larger plains in the country and terrains built by solid rocks (limestone, marble, andesite etc.), especially in the western part, show low landslide susceptibility. However, the field studies found that even there the occurrence of (smaller) landslides is not totally excluded (near channels, roads, constructions, and other sites with substantial anthropogenic activities).

The LS approach implemented in this work can be further improved in combination with statistical methods if larger and more reliable landslide inventory database is prepared [42] and if other triggering factors (TWI, SPI etc.) are evaluated.

The ultimate goal of producing an accurate LS map that willcover the entire country is not only to indicate endangered areas but to take actions and activities toward prevention and decreasing of the hazard risk itself. If applied properly, such maps are suited for minimizing or avoiding future risks and damages [43]. Nevertheless, in Macedonia, national funds are primarily used for recovery from damages by landslides, and much less for prevention and especially in producing quality mass-movement susceptibility models and maps. In that sense, this model is the first attempt on the country level hoping that further improvement will be made soon.

\section{REFERENCES}

[1] D. Kolčakovski, I. Milevski, Recent Landform Evolution in Macedonia. In Recent Landform Evolution. The Carpatho-Balkan-Dinaric Region., Loczy D., Stankoviansky M., K. A., Ed.; Springer (2012), pp. 413-442.

[2] I. Milevski, S. Dragicevic, GIS-Based Landslide Susceptibility Modelling of the Territory of the Republic of Macedonia. 7th International Conference on Cartography and GIS, Sozopol, (2018), pp. 82-91.

[3] D. J. Varnes, Landslide hazard zonation: a review of principles and practice; United Nations Educational, Scientific and Cultural Organization: Paris, 1984, pp. 1-63.

[4] M. Crozier, Landslides: causes, consequences and environment; Croom Helm: London, 1986; p 252.

[5] R. Soeters, C. J. van Westen, Slope instability recognition, analysis, and zonation. In A. K. Turner, \& R. L. Schuster (Eds.), Landslides, investigation and mitigation ( Transportation Research Board, National Research Council, Special Report; 247) Washington D.C., USA, (1996), pp. 129-177.

[6] F. Guzzetti, A. Carrara, M. Cardinali, P. Reichenbach, Landslide hazard evaluation: A review of current techniques and their application in a multi-scale study, Central Italy. Geomorphology, 31 (1-4) (1999), pp. 181-216.

[7] L. Luzi, F. Pergalani, Slope instability in static and dynamic conditions for urban planning: The 'Oltre Po Pavese' case history (Regione Lombardia Italy). Natural Hazards 20 (1), (1999), pp. 57-82.

[8] M. J. Crozier, T. Glade, Landslide Hazard and Risk: Issues, Concepts and Approach. In Landslide Hazard and Risk, 2012, pp. 1-39.

[9] F. Guzzetti, P. Reichenbach, F. Ardizzone, M. Cardinali, M. Galli, Estimating the quality of landslide susceptibility models. Geomorphology $\mathbf{8 1}$ (1-2), (2006), pp. 166-184.

[10] E. E. Brabb, E. H. Pampeyan, Preliminary map of landslide deposits in San Mateo County, California. US Geological Survey Miscellaneous Field Studies, 1972, Map MF-360, scale 1:62.500 (reprinted in 1978)

[11] C. J. van Westen, N. Rengers, M. Terlien, R. Soeters, Prediction of the occurrence of slope instability phenomenal through GIS-based hazard zonation. Geologische Rundschau, Vol. 86 (1997), pp. 404-414. https://doi.org/10.1007/s005310050149

[12] C. Gokceoglu, H. Sonmez, H.A. Nefeslioglu, T.Y. Duman, T. Can, The 17 March 2005 Kuzulu 
landslide (Sivas, Turkey) and landslidesusceptibility map of its near vicinity. Engineering Geology 81 (2005), pp. 65-83.

[13] C. J. van Westen, GIS in landslide hazard zonation: a review, with examples from the Andes of Colombia. In Mountain environments \& geographic information systems; In M. F. Price, \&. D. I. H., Ed.; Taylor \& Francis: London, 1994, pp. 135-166.

[14] A. Carrara, M. Cardinali, F. Guzzetti, P. Reichenbach, GIS Technology in Mapping Landslide Hazard. In Geographical Information Systems in Assessing Natural Hazards. Advances in Natural and Technological Hazards Research, vol 5. Springer, 1995; pp. 135-175.

[15] P. Aleotti, R. Chowdhury, Landslide hazard assessment: Summary review and new perspectives. Bulletin of Engineering Geology and the Environment 58 (1), (1999), pp. 21-44.

[16] L. Cascini, Applicability of landslide susceptibility and hazard zoning at different scales. Engineering Geology 102 (3-4), (2008), pp. 164-177.

[17] J. D. Jiménez-Perálvarez, C. Irigaray, R. El Hamdouni, J. Chacón, Building models for automatic landslide-susceptibility analysis, mapping and validation in ArcGIS. Natural Hazards, 50-3 (2009); pp. 571-590.

[18] I. Milevski, B. Markoski, S. Gorin, M. Jovanovski, Application of Remote Sensing And GIS in Detection of Potential Landslide Areas. International Symposium Geography and Sustainable Development, Ohrid, 2009, pp. 453-463.

[19] I. Milevski, S. Dragicevic, A. Georgievska, GIS and RS-based modelling of potential natural hazard areas in Pehchevo municipality, Republic of Macedonia. Zbornik radova Geografskog instituta Jovan Cvijic, SANU, 63-3 (2013), pp. 95-107.

[20] E. Ivanova, I. Milevski, Landslide Susceptibility Mapping of the Territory of Municipalities Pehchevo and Simitli by Means of GIS Modeling. Proceedings from the Conference Space, Ecology, Safety SES-2013, Sofia, 2014; pp. 434-443.

[21] I. Milevski, E. Ivanova, GIS- and RS-based modelling of potential natural hazard areas in mountains. Case study: Vlahina mountain. In Sustainable Mountain Regions: Challenges and Perspectives in Southeastern Europe; Koulov B., Z. G., Ed.; Springer: Cham, 2016, pp. 191-204.

[22] I. Milevski, S. Dragicevic, I. Radevski, GIS and Remote Sensing based natural hazard modelling of Kriva River catchment, Republic of Macedonia. Zeitschrift fur Geomorphologie 61 (Supplementary issue 2), (2017), pp. 213-228.

[23] I. Peševski, Landslide susceptibility modeling using GIS technology; $\mathrm{PhD}$ dissertation-manuscript, Ss. Cyril and Methodius, Skopje, (2015).
[24] H. Proske, C. Bauer, Indicative hazard maps for landslides in Styria; Austria. Acta Geobalcanica 2 (2), (2016), pp. 93-101.

[25] T. L. Saaty, The Analytical Hierarchy Process, McGraw Hill, New York, 1980, pp. 1-287.

[26] A. Ishizaka, A. Labib, Review of the main developments in the analytic hierarchy process, Expert Syst, Appl, 38, (2011), pp. 14336-14345. DOI: $10.1016 /$ j.eswa.2011.04.143.

[27] W. Ho, Integrated analytic hierarchy process and its applications - A literature review, Eur. J. Oper. Res., 186, (2008), DOI: 10.1016/j.ejor.2007.01.004. pp. 211-228.

[28] M. Komac, Landslide susceptibility model using the Analytical Hierarchy Process method and multivariate statistics in perialpine Slovenia. Geomorphology 74, (2006), pp. 17-28.

[29] A. Yalcin, S. Reis, A. C. Aydinoglu, T. Yomralioglu, A GIS-based comparative study of frequency ratio, analytical hierarchy process, bivariate statistics and logistics regression methods for landslide susceptibility mapping in Trabzon, NE Turkey. Catena 85 (3) (2011), pp. 274-287.

[30] T. L. Saaty, L. G. Vargas, Models, Methods, Concepts, and Applications of the Analytic Hierarchy Process. 1st ed. Kluwer Academic, Boston, 2001, pp. 1-333.

[31] L. Donati, M. C. Turrini, An objective method to rank the importance of the factors predisposing to landslides with the GIS methodology: Application to an area of the Apennines (Valnerina; Perugia, Italy). Engineering Geology 63 (3-4)(2002), pp. 277-289.

[32] B. Komac, M. Zorn, Statistical landslide susceptibility modeling on a national scale: the example of Slovenia. Revue Roumaine de Géographie 53-2 (2009), pp. 179-195.

[33] K. Terzaghi, Mechanisms of landslides. In Application of Geology to Engineering Practice; Paige, S., Ed.; American Geological Society, (1950), pp. 83-124.

[34] C. Chalkias, M. Ferentinou, C. Polykretis, GISBased Landslide Susceptibility Mapping on the Peloponnese Peninsula, Greece. Geosciences 4 (3), (2014), pp. 176-190.

[35] A. Jaafari, A. Najafi, H. R. Pourghasemi, J. Rezaeian, A. Sattarian, GIS-based frequency ratio and index of entropy models for landslide susceptibility assessment in the Caspian forest, northern Iran. International Journal of Environmental Science and Technology 11 (4) (2014), pp. 909-926.

[36] Y. Tanaka, Differences of Landslide Occurrences Behavior Due to Slope Aspects in the Amehata River Basin. American Geophysical Union, Fall Meeting, 2005. 
[37] K. D. Goepel, Implementing the Analytic Hierarchy Process as a Standard Method for MultiCriteria Decision Making In Corporate Enterprises - A New AHP Excel Template with Multiple Inputs, Proceedings of the International Symposium on the Analytic Hierarchy Process, Kuala Lumpur 2013.

[38] M. Jovanovski, I. Milevski, J. B. Papić, I. Peševski, B. Markoski, Landslides in the Republic of Macedonia triggered by extreme events in 2010. In Geomorphological Impacts of Extreme Weather: Case Studies From Central and Eastern Europe, Geomorphol ed.; Denes Loczy, Ed.; Springer, (2013), pp. 265-280.

[39] G. F. Jenks, Optimal data classification for choropleth maps; Dept. Geography, Univ. Kansas: Kansas, 1977, pp. 1-24.
[40] L. Stegna, F. Csillag, Statistical determination of class intervals for maps. The Cartographic Journal 24 (2) (1987), pp. 142-146.

[41] T. Fawcett, An introduction to ROC analysis. Pattern Recognition Letters 27 (8), (2006), pp. 861-874.

[42] H. R. Pourghasemi, B. Pradhan, C. Gokceoglu, D. K. Moezzi, Landslide Susceptibility Mapping Using a Spatial Multi Criteria Evaluation Model at Haraz Watershed, Iran. B. Pradhan and M. Buchroithner (eds.), Terrigenous Mass Movements, Springer-Verlag Berlin Heidelberg, 2012, DOI:10.1007/978-3-642-25495-6_2, pp. 23-49

[43] B. Singh, R. K. Goel, Landslide hazard zonation. In Rock Mass Classification, 1st ed.; Elsevier Science, 1999, pp. 184-199.

\title{
ЗОНИРАЊЕ НА ПОДЛОЖНОСТ ОД СВЛЕЧИШТА НА ТЕРИТОРИЈАТА НА РЕПУБЛИКА МАКЕДОНИЈА, СО ПРИМЕНА НА АНР (ANALYTICAL HIERARCHY PROCESS APРROACH) ПРИСТАП
}

\author{
Ивица Милевски ${ }^{1}$ Славољуб Драгиќевиќ \\ ${ }^{1}$ Природно-математички факултет, Универзитет Св. Кирил и Методиј, Скопје, Република Македонија \\ ${ }^{2}$ Географски факултет, Универзитет во Белград, Србија
}

Свлечиштата се природни непогоди кои имаат големо негативно влијание во многу подрачја низ светот, вклучувајќи ја и Република Македонија. Овде се регистрирани бројни фосилни и рецентни свлечишта, а при поинтензивни врнежи или топење на снег, често се активираат нови. Тие предизвикуваат значителни материјални штети, а понекогаш и човечки жртви (како што било со свлечиштето на ридот Градот во Кавадарци во 1956 година). Во таа смисла, моделирањето и зонирањето на подрачјата подложни на појава на свлечишта е од особено значење, особено при планирање на користење на просторот. Од неодамна, за оваа намена се користат современи ГИС-пристапи, главно за помали територии, а во последно време и за регионален до државен опфат. Во таа смисла, овој труд е прв обид да се изработи модел на зони со различен степен на подложност на свлечишта. Притоа, користен е аналитичко-хиерархискиот пристап (АНР) кој се базира на рангирање на значењето на факторите што влијаат на појавата на свлечишта. Во постапката се избрани 6 фактори, и тоа: наклони на теренот, литологишки состав, покровност и користење на земјиштето, тип на наклон (конкавен или конвексен), близина до реки и близина до патишта. Рангирањето е изведено со помош на експертски оцени за значењето на наведените фактори изнесени во досегашната релевантна библиографија, како и на статистичка анализа на локацијата на регистрираните (270) свлечишта во однос на секој од дадените фактори. Всушност, во рамките на секој фактор одделно се издвоени класи на кои според горенаведениот принцип им е доделена различна „тежина“. Со собирање на сите „тежински“ вредности за факторите и класите во рамките на нив, преку растерски леери во софтверскиот пакет SAGA GIS е добиен модел на подложност на свлечишта за целата територија на државата. Вредностите од овој модел, кои се движат помеѓу 2.5 и 26 , се поделени во 5 зони: од зона со најмала (или без) подложност на свлечишта, до зона со многу голема подложност (веројатност) за појава на свлечишта. Моделот е проверен детално со т.н. функција на ROC-крива, при што е добиен солиден резултат од 0.78 или 78 \% точност. Понатаму останува овој приод да се дополни со методот на статистичка веројатност или фреквенција за добиениот резултат да биде уште подобар. За такво нешто, пак, неопходна е подетална датабаза на свлечишта во државата.

Клучни зборови: подложност на свлечишта; зонирање; AHP; ROC;AUC 